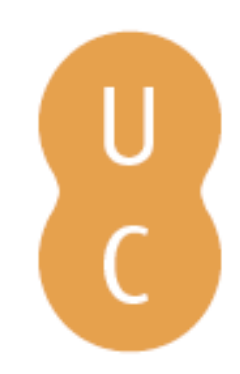

\title{
nommalina
}

\section{Physical development of young talented tennis players} \begin{abstract}
Autor(es): $\quad \begin{aligned} & \text { Kramer, Tamara; Huijgen, Barbara; Elferink-Gemser, Marije T.; Lyons, } \\ & \text { Jim; Visscher, Chris }\end{aligned}$
\end{abstract}
Publicado por: Imprensa da Universidade de Coimbra

URL

persistente: URI:http://hdl.handle.net/10316.2/38854

DOI: $\quad$ DOI:http://dx.doi.org/10.14195/978-989-26-1169-3_7

Accessed : $\quad$ 26-Apr-2023 09:07:54

A navegação consulta e descarregamento dos títulos inseridos nas Bibliotecas Digitais UC Digitalis, UC Pombalina e UC Impactum, pressupõem a aceitação plena e sem reservas dos Termos e Condições de Uso destas Bibliotecas Digitais, disponíveis em https://digitalis.uc.pt/pt-pt/termos.

Conforme exposto nos referidos Termos e Condições de Uso, o descarregamento de títulos de acesso restrito requer uma licença válida de autorização devendo o utilizador aceder ao(s) documento(s) a partir de um endereço de IP da instituição detentora da supramencionada licença.

Ao utilizador é apenas permitido o descarregamento para uso pessoal, pelo que o emprego do(s) título(s) descarregado(s) para outro fim, designadamente comercial, carece de autorização do respetivo autor ou editor da obra.

Na medida em que todas as obras da UC Digitalis se encontram protegidas pelo Código do Direito de Autor e Direitos Conexos e demais legislação aplicável, toda a cópia, parcial ou total, deste documento, nos casos em que é legalmente admitida, deverá conter ou fazer-se acompanhar por este aviso.

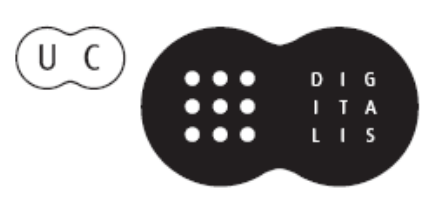




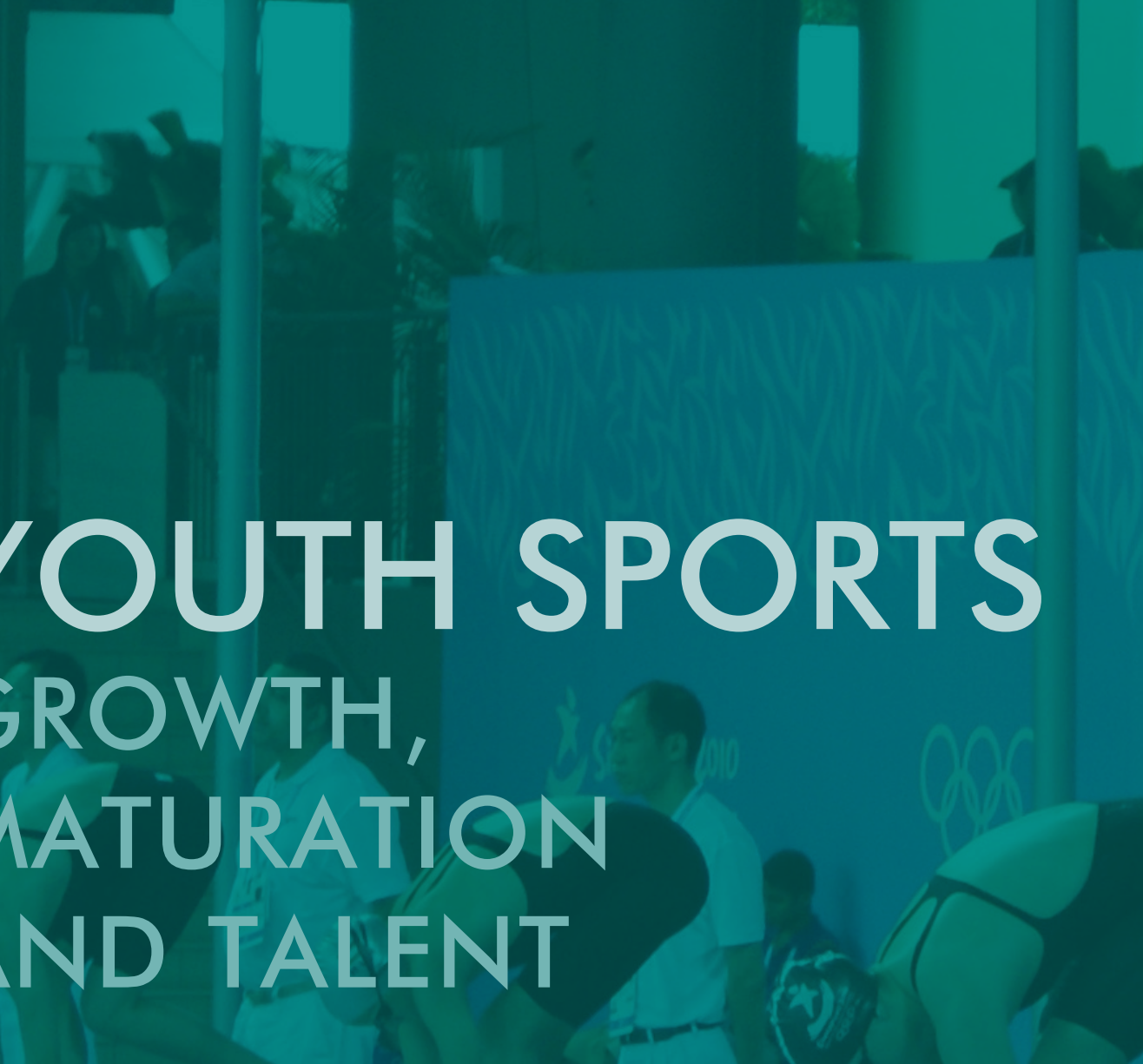

MANUEL J. COELHO E SILVA ANTÓNIO J. FIGUEIREDO MARIJE T. ELFERINK-GEMSER ROBERT M. MALINA

\section{EDITORS}

2. ' EDIÇÃO

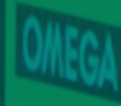

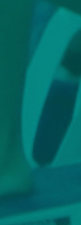




\section{CHAPTER 7: PHYSICAL DEVELOPMENT OF YOUNG TALENTED TENNIS PLAYERS}

Tamara Kramer

Barbara Huijgen

Marije T Elferink-Gemser

Jim Lyons

Chris Visscher

\section{INTRODUCTION}

"Talent" can be defined as ability above the normative average. Talented athletes perform better than peers during training and competition and have the potential to reach elite level (e.g., Elferink-Gemser, Visscher, Lemmink \& Mulder, 2004; Helsen, Hodges, Van Winckel \& Starkes, 2000; Howe, Davidson \& Sloboda, 1998). Talent selection and identification, therefore, become important determinants of success in sport. They have been defined as the prediction of future performance of for example young tennis players or the identification of young players that will achieve success at national or international levels (MacCurdy, 2006). In tennis, there are many aspects that must be well developed to become a professional player. These components are physiological, physical, psychological, technical, and tactical (MacCurdy, 2006). According to MacCurdy (2006), physiological components are considered to be defined by height, weight as well as other anthropometric elements with physical aspects (e.g., running, jumping, agility, and power).

Psychological components are defined by levels of self-confidence, self-esteem, personality and motivation. Technical and tactical skills, however, are probably the most important aspects. Technique is important for being able to execute the correct moves with a minimum of error, whereas tactics refer to the ability to make rapid and correct decisions as play unfolds (MacCurdy, 2006). As might be expected, all of these aspects are better developed in talented as opposed to average tennis players although they must be further developed during youth and adolescence in order for talented players to advance to level of professional. While recognizing the relative importance of the psychological, technical, and tactical components of the skill, this review will concentrate on the physical attributes of a tennis player. 
Tennis is an intermittent anaerobic sport, involving quick stops and starts, with an aerobic recovery phase (Fernandez, Mendez-Villanueva \& Pluim, 2006). Research with regard to the physical development of young talented tennis players is not extensive. However, it is of relevance to know which aspects are important to become an elite senior player and how these aspects develop through the years from junior to senior elite player. Kovacs (2007), however, proposes that three general physical skills (anaerobic, aerobic and auxillary), and their constituent subcomponents, are important for tennis performance (figure I). The anaerobic components include speed, agility, strength, power and muscular endurance. Speed refers to the running speed on court and off court and tennis specific speed (Kovacs, 2006). For a tennis player it is important to reach high velocity during the first meters of the sprint to the ball. Agility is the way of moving on the tennis court, for example, sprinting with changes of direction. In tennis you need to be able to change direction quickly to get to the ball (Kovacs, 2006). Thus, speed and agility are the ability to move around the court quickly and smoothly to position for a shot (Roetert, Piorkowski, Woods \& Brown, 1995). Strength of the body parts and the power of the body are also anaerobic components and therefore also part of this review. Strength is the amount of weight you can lift or handle at any one time (Roetert et al., 1995). Strength is important for hitting the ball hard, however, also necessary for preventing injuries (Kovacs, 2006). Power is the amount of work one can perform in a given period (Roetert et al., 1995). Power is necessary for al the explosive movements that a player makes on the court (Kovacs, 2006). Muscular endurance is the number of times a muscle can lift a weight or how long muscles can hold an amount of weight (Roetert et al., 1995). Strokes in tennis could be very long, thus requiring good muscular endurance for hitting the ball hard constantly.

The aspects of the aerobic component are muscular and aerobic endurance. Muscular endurance, as mentioned earlier, is the number of times a muscle can lift a weight or how long muscles can hold an amount of weight (Roetert et al., 1995). In a tennis context, this is important for prolonged rallies later in the match. Aerobic endurance, on the other hand, refers to the ability to take in, transport and use oxygen (Roetert et al., 1995). In a study by Banzer, Thiel, Rosenhagen \& Vogt (2008) it was found that VO 2 max is a good indicator for the performance of a tennis player. $\mathrm{VO}_{2 m a x}$ is the highest rate at which a player can consume oxygen during exercise, which reflects the aerobic fitness of a player. The higher the $\mathrm{VO}_{2} \max$ of the player was the higher the rank of the player on the world ranking list was (Armstrong, Welsman \& Winsley, 1996). Thus for aerobic capacity, the $\mathrm{VO}_{2} m a x$ is one of the outcome variables. 


\section{Physical components}

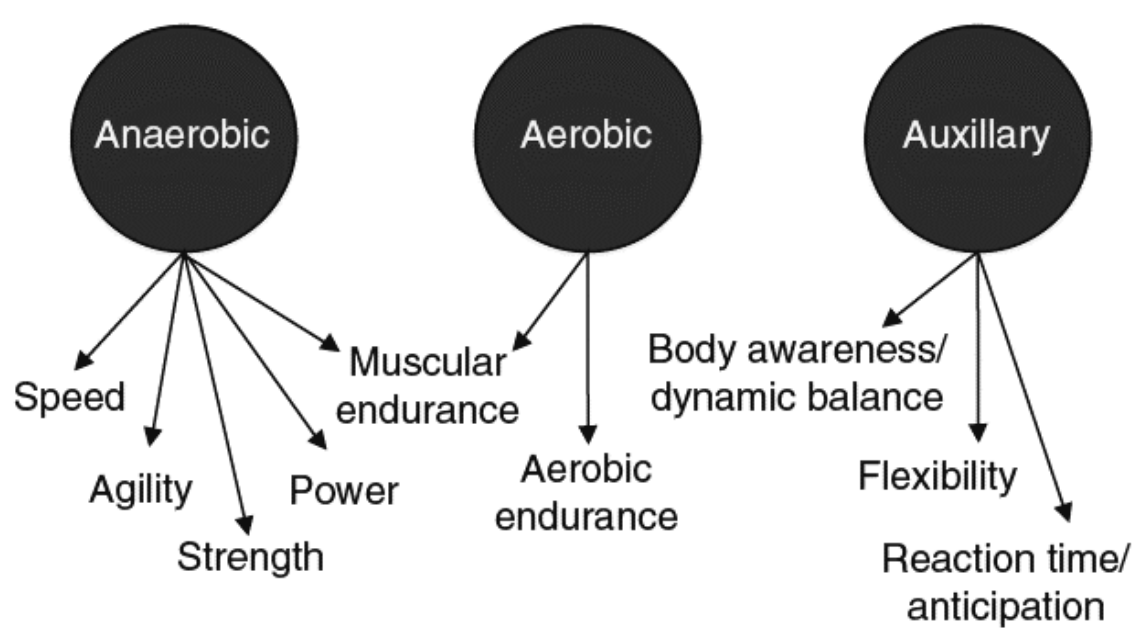

Figure I. The physical skills and components relevant to tennis performance. Adjusted from Kovacs (2007).

The third physical component is termed auxillary. This component includes body awareness, dynamic balance, flexibility, reaction time and anticipation. The ability to recognize different parts of one's own body, and their relative positions is called body awareness. It is essential for performing smooth, coordinated movements, and must be well-developed in tennis Dynamic balance is necessary for tennis players, because they have to sprint, followed by quickly standing still to play a ball and they have to be in balance all the time. Flexibility is the motion that is available at a joint (Roetert et al., 1995). Flexibility is important for protecting against injuries (Chandler, Kibler, Stracener, Ziegler \& Pace, 1992). Reaction time is needed for being able to react quickly on fast services or fast returns or strokes. Because of the interaction between the players on both sides of the net, anticipation of what the other players is going to do is an important aspect to develop.

Another study was found that tried to identify the normative scores for tennis talents (Roetert et al., 1995). In the study of Roetert, Garret \& Brown (1992) it was found that physical performances are strongly related to ranking. The better the physical performance, the higher the ranking was. The aim of this review is to give an inside in the state of the art about development of physical performances in young talented tennis players. 
Secondary aims of this review are to investigate if differences exist between the development of boys and girls in this area and if differences exist between elite and sub-elite tennis players.

\section{METHODS}

The limiting terms of the study were that the age of the population that has been studied in the articles were between 6-30 years. Articles with players in the age 6-18 years were preferred, although, articles with players aged between 18 and 30 years old were also allowed. The elite tennis players in this review are players that compete at an international or national level and the sub-elite tennis players are players that compete at a regional level. The non-elite players are players that are not better than the average tennis player. Only English written articles were included and all research designs were included. The searches were conducted using three common academic search engines: PubMed, LiveTrix and Google Scholar. There were no restrictions on publication dates of the articles. Search terms were based on the components for performance detailed by Kovacs (2007) as well as terms commonly associated with the game of tennis and with tennis players. Thus, the search terms used were tennis, racquet sport, talents, elite, adolescence, youth, performance, development, anaerobic, aerobic, physiological, physical, endurance, agility, speed, power, strength, muscular, flexibility, dynamic balance, body awareness, reaction time, anticipation, field test and on-court. Combinations of these search terms were also used. The reference sections of the articles identified via the search terms were also used to identify potentially relevant sources that may have been omitted in the initial search. The selection criteria for the articles used in this review were based upon the article title and the abstract of the article.

\section{RESULTS}

The search terms returned a total of 60 articles of which 17 were used for the components anaerobic, aerobic and auxillary. Of the 60 articles, 43 were excluded because these studies did not measure physical components that are in line with the interest of this review. Several articles included more than one component, and therefore all are included in the current review. For the anaerobic components, seven articles were found. The search for aerobic component produced 13 articles and for the auxillary component six articles were found. In the article of Kovacs, Pritchett, Wickwire, Green \& Bishop (2007) age of the tested tennis players is not given, however since the players are college males, the assumption is that these males are between 18 and 22 years old. 


\section{Anaerobic component}

\section{a) Speed}

For the sub-component speed, three articles were found. Speed in earlier tennis research was measured with over 5 metres, 10 metres and over 20 metres (Berg, Coetzee \& Pienaar, 2006; Kovacs et al., 2007; Kraemer et al., 2003). These tests were simple sprints. Table I shows the results (see appendix). In the study of Berg et al. (2006), they compared early, middle and late maturation girls with each other. The late maturation group were the fastest on the 5 meter and 10 meter sprint. The second best were the early maturation group and than the middle maturation group. The studies of Kovacs (2007) and Kraemer et al. (2003) did not compare different groups of age. Furthermore, these studies could not be compared with each other because one study measured males and the other measured females. Males were faster than females on the speed tests.

\section{b) Agility}

A total of five articles were found that measured the agility sub-component however the tests that were used differed from each other. Berg et al. (2006) used the AIS test for agility (the AIS test was not explained in the article). Kovacs et al. (2007) used the spider test to measure the agility. With the spider test, a player picks up five tennis balls and places them in a rectangle behind the center of the baseline. The balls are located on the crossing of the single sideline with baseline, on the crossing of the service line and single sideline cross, and on the split of the service line with the middle service line. The total distance is not known from the article.

Kraemer et al. (2003) used a lateral agility test using regulation-sized tennis racquets modified from the USTA agility test protocol (United States Tennis Association, 1998). In this test, a tennis player has to move form the middle of the field $4.12 \mathrm{~m}$ to the forehand side, move back to the middle and then move to her backhand side.. The time it takes to execute this twice is the score. For further explanation of the test see Kraemer et al. (2003).

Roetert et al. (1992) also used the spider test (see above) and the hexagon test. The hexagon test is a test on the tennis court at which a hexagon is drawn with angles of 120 degrees and 24 inches (0.6I metre) per 
side. The player stands in the middle and jumps over a side of the hexagon and jumps back into it in a clockwise manner. The time this takes would be the score. Roetert et al. (1995) used the spider test, hexagon test and the lateral agility test to measure the agility The results of the articles are shown in table I (see appendix).

The AIS test could not be compared with other research, because no other articles using this test were revealed by the search. For the spider test, it was found that players got faster with increasing age. Only elite players were measured and males are faster than females across all age categories $(12,14$ and 16 years). For the lateral agility test, at the age of 12 there are no differences in speed between the females and males. Looking at the age of 14 and 16, it was found that the males are faster. Again only elite players were measured. The hexagon test showed that males are faster at the age of 12 and 14, however, females are faster at the age of 16 years. Also with this test there only elite were players measured.

\section{c) Strength}

For the sub-component strength, eight articles were found in which strength is measured in different ways (Bencke et al., 2002; Berg et al., 2006; Bloomfield, Blanksby, Beard, Ackland \& Elliot, 1984; Kovacs et al., 2007; Kraemer et al., 2003; Perry, Wang, Feldman, Ruth \& Signotile, 2004; Roetert et al., 1992; Roetert et al., 1995). Grip strength, arm flexion, arm extension, thigh flexion and leg extension were the measurements. Grip strength was measured with a hand grip dynamometer (Berg et al., 2006; Bloomfield et al., 1984; Kovacs et al., 2007; Kraemer et al., 2003; Perry et al., 2004; Roetert et al., 1992; Roetert et al., 1995). Arm flexion was measured isometric with a dynamometer and sitting on a chair (Bencke et al., 2002; Bloomfield et al., 1984). Thigh flexion and leg extension were both measured by following the procedure developed by Clarke (1976). The results of these measurements are shown in table 2 (see appendix). It was found that that grip strength increased as function of age and males scored higher on grip strength than females across all ages. Elite players scored higher than the sub-elite players on grip strength and arm flexion strength. For thigh flexion and leg extension strength, it was found that strength increases with age. 


\section{d) Power}

The search for articles that measured power revealed seven articles. The power measurements used in earlier research are vertical counter movement jump, squat jump and the Wingate test (Bencke et al., 2002; Berg et al., 2006; Bloomfield et al., 1984; Kovacs et al., 2007; Kraemer et al., 2003; Roetert et al., 1992; Roetert et al., 1995). Vertical counter movement jump is a jump in which the feet of the player are standing shoulder width apart and the player can only use his/her arms to jump as high as possible. The jump height in centimetres is the score (Bencke et al., 2002; Berg et al., 2006; Bloomfield et al., 1984; Kraemer et al., 2003; Roetert et al., 1992; Roetert et al., 1995).. With the squat jump, the player is already standing in squat position and than jumps as high as possible (Bencke et al., 2002). The Wingate test is performed on a cycle ergometer (Bencke et al., 2002; Kovacs et al., 2007; Kraemer et al., 2003). The players have to pedal as fast as possible for 30 seconds while the corresponding power is calculated. The power of a players, is the number of watts per kilogram body weight that a person can pedal for 30 seconds.

The results of these articles are shown in table 3 (see appendix). The articles showed that, for the jump data, elite scored better than non-elite and that power increased with age. The males had higher power scores than the females. For the Wingate data, it was shown that the elite females scored lower than the non-elite females. For the males the elite males scored higher than the non-elite males.

\section{d) Anaerobic muscular endurance}

No articles were found about the development of anaerobic muscular endurance in young tennis players.

\section{Aerobic component}

\section{a) Aerobic muscular endurance}

No articles were found about the development of aerobic muscular endurance in young tennis players.

\section{b) Aerobic endurance}

A total of 13 articles were found for aerobic endurance. Results show that the aerobic endurance development of young tennis players are mostly measured by $\mathrm{VO}_{2}$ max, heart rate during testing, as well with a 1 1/2 mile run (Armstrong 
et al., 1996; Baxter-Jones, Goldstein \& Helms, 1993; Bergeron et al., 1991; Cooke \& Davey, 2008; Faff, Ladyga \& Starczewska-Czapowska, 2000; Girard, Chevelier, Levegue, Micallef \& Millet, 2006; Kovacs et al., 2007; Kraemer et al., 2003; Leone, Lariviere \& Comtois, 2002; Perry et al., 2004, Roetert et al., 1992; Roetert et al., 1995). The $\mathrm{VO}_{2} \mathrm{max}$ (explained in the introduction) is measured on a treadmill (Armstrong et al., 1996; Baxter-Jones et al., 1993; Bergeron et al., 1991; Cooke et al., 2008; Faff et al., 2000; Girard et al., 2006; Kovacs et al., 2007; Kraemer et al., 2003; Leone et al., 2002; Perry et al., 2004). During the $11 / 2$ mile run, the purpose is to run as fast as possible and the time it takes to complete this is the score (Roetert et al., 1992; Roetert et al., 1995). Only Berg et al. (2006) measured aerobic endurance with a shuttle run test. The shuttle run test is taken following the protocol given by the Australian coaching council (1998).

In table 4 (see appendix) the results of these articles are shown. Males have a higher $\mathrm{VO}_{2} \max$ than females in all studies. The studies also showed that the $\mathrm{VO}_{2}$ max of males increases until they are 18 years old. The $\mathrm{VO}_{2}$ max of females increased during young adolescence (age 10 until 16), although, slightly decreased if the females are approximately 16 years old. Middle maturation females scored the best on the shuttle run test, the second best were the late maturation females and then the early maturation females. The time for the $11 / 2$ mile run is faster for males than for females. And when players get older they get faster on the I $1 / 2$ mile run. Overall, the elite players scored higher on all aerobic tests than the sub-elite players.

\section{Auxillary component}

\section{a) Body awareness/dynamic balance}

No articles were found regarding the development of body awareness or dynamic balance in young tennis players.

\section{b) Flexibility}

A total of six articles were found that measured flexibility. The measurements included internal and external shoulder rotation, hamstring flexibility, arm flexion, gastrocnemicus, quadriceps, thigh rotation, ankle flexion and hip flexibility (Berg et al., 2006; Bloomfield et al., 1984; Chandler et al., 1990; Kibler \& Chandler, 2003; Kovacs et al., 2007; Leone et al., 2002; Perry et al., 2004). In the article of Roetert \& Ellenbecker (1998), a description of the shoulder internal and external flexibility test, and the hamstring flexibility test that Berg et al. (2006) used can be found. The method of measurement that were used 
in the article of Bloomfield et al. (1984), can be found in the book of Clarke (1976). All these flexibility measurements were done in degrees.

Chandler et al. (1990) measured shoulder flexibility with the athlete supine, the scapula stabilized, the shoulder abducted to 90 degrees, and the glenohumeral joint rotated into maximum internal and external rotation. Hamstring flexibility was measured with one leg of the athlete on the table, and the opposite leg actively raised and flexing the hip while keeping the knee fully extended. The quadriceps flexibility was measured with one leg of the athlete flexed at the hip and the knee held with the band close to the chest. The measured leg hung off the side of the table and the knee was flexed actively, and then taken the point of tension for the measurement to be taken. Gastrocnemicus flexibility was measured with the knee of the athlete in complete extension and the foot maximally dorsiflexed.

Kibler et al. (2003) measured shoulder rotation, hamstring flexibility, gastrocnemicus flexibility and quadriceps flexibility. The shoulder rotation was measured with supine with 90 degrees humeral adduction and than rotated internally or externally. Hamstring flexibility was measured supine and flexion of the hip measured while the leg is extended. Gastrocnemius was measured supine with straight leg and then making a dorsiflex movement in the ankle. The quadriceps flexibility was measured while the subject lying on a table with the leg of the side and then flexing the knee.

Kovacs et al. (2007) measured the internal and external shoulder range of motion (ROM). The players were tested in a supine position with 90 degrees of glenohumeral joint abduction. The universal goniometer axis was aligned with the long axis of the humerus, with the distal most tip of the olecranon being the superficial landmark for alignment. The stationary arm of the goniometer was placed in a vertical position with the moving arm aligned with the lateral aspect of the ulna. Starting at the anatomical zero rotation position in 90 degrees of abduction, the players were asked to maximally externally rotate their shoulder. Hamstring flexibility was measured similarly in Chandler et al. (1990). Hip flexibility was measured as described in Ross, Nordeen \& Barido (2003). Quadriceps flexibility was measured so that the participants lay prone on a table and the goniometer was set so that the stationary arm was aligned with the greater trochanter; the moving arm was aligned with the fibular head and lateral malleolus. The axis was placed over the lateral femoral epicondyle. Passive ROM in the sagittal plane was then assessed with the involved knee beginning at 90 degrees from the table (horizontal) and then the participant was instructed to flex the knee while maintaining a neutral spine. 
In the article by Perry et al. (2004), shoulder rotation was measured while the subject was lying on a hard and flat surface with the shoulder of the dominant side stabilized and arm abducted to 90 degrees. The players were asked to rotate their glenohumeral joint to pain-free range of motion first internally and second externally.

The results are shown in table 5 (see appendix). They show that flexibility decreases with age however there are no differences between elite and sub-elite tennis players. It should be noted here that not all the measurements were done in both groups. The females are more flexible in general than males.

\section{c) Reaction time/ anticipation}

No useful articles were found about development of reaction time or anticipation.

\section{DISCUSSION}

The aim of this review was to gain insight into the physical factors underlying the development of young talented tennis players. Secondary aims of this review were to investigate if differences exist between the development of males and females in this area and if differences exist between elite and subelite tennis players. In summary, the results suggest that for all three physical components identified by Kovacs (2007), anaerobic, aerobic and auxillary, the elite players scored higher than the sub-elite or the non-elite and males scored higher than females in general. For the anaerobic component aspect of speed, it was found that elite players scored higher than sub-elite players and that males scored higher than females. In terms of agility, it was found that males are faster than females in general, and for speed it was found that speed increased by an increase of age. During late adolescence, higher scores on strength were found during the early youth, and males scored higher than females. The elite tennis players scored higher than the sub-elite players. Power increases with age and males have greater power than females. Elite female players scored lower on the Wingate test than sub-elite female players although elite male players scored higher on the Wingate test than sub-elite males. With respect to the aerobic endurance aspect, it was found that males improve to a greater degree with age than do females. VOzmax in females peaking at age 16. In general, males scored higher than females on all the aerobic endurance tests and the same is the case for elite players compared with sub-elite players. Earlier studies regarding the auxillary sub-component only considered flexibility with this characteristic. Flexibility decreasing with age for both genders but with females were more flexible than males overall. 
There were no consistent differences in flexibility between elite and sub-elite tennis players.

The aspect speed was measured with tests over short distances $(5,10$ and $20 \mathrm{~m}$ ). The three different articles that measured speed used the same tests. However, these researchers only measured one group of elite tennis players who were 18-22 years old. The rest of the players were sub-elite players thus comparisons of these groups with each other is difficult. The elite group was faster than the sub-elite, however the elite players were older and males were compared with younger sub-elite females (Berg et al., 2006; Kovacs et al., 2007; Kraemer et al., 2003). More information regarding the speed of talented tennis players would be necessary for comparing elite groups of different ages and to determine appropriate reference values. It is interesting that there is so little information regarding speed in the tennis physiology literature. This is particularly true given that it is such an important aspect of the game. Simply put, the faster a tennis player can get to the ball the more time a he/she has to prepare for a shot (Roetert et al., 1995). In earlier cross-sectional research, it was found that talented youth soccer players show improvement on sprinting tests with increasing age (Rosch et al., 2000; Vanderford, Meyers, Skelly, Stewart \& Hamilton, 2004). It can be hypothesized that these results might also be found in a group of tennis players with different ages, however, further research is needed to test this hypothesis.

The anaerobic component agility allows for a player to be in the correct position and provides a solid platform from which to hit the ball (Roetert et al., 1995). Agility is crucial to good court movement (Salonikidis \& Zafeiridis, 2008). Agility tests were seen as the most important predictor for ranking the junior tennis players (Kovacs, 2006). Only one study however (Roetert et al., 1995), compared different age groups across this dimension. This study showed that males and females showed increased agility at increasing ages. A reason for this might be the natural processes of growth and maturation (Nedeljkovic, Mirkov, Kukolj, Ugarkovic \& Jaric, 2007). For example, longer legs could help to be faster. Roetert et al. (1995) also showed that males have better agility than females. This could be explained by the assumption that females have higher fat percentage than males and this could explain why the males are faster (Praagh \& Dore, 2002), beacause higher fat percentage leads to less muscles and thus lower agility. The current review showed that sub-elite players are less fast on the agility tests than elite tennis players. This could show that agility is an important factor and maybe a differentiated factor for being elite or a sub-elite player.

On reason that strength is important in tennis is for reducing injuries (Roetert et al., 1995). The results presented in the reviewed literature suggest that elite tennis players are stronger than sub-elite or non-elite tennis players. 
In general, elite players train more often than sub-elite or non-elite tennis players. For elite players, strength is perhaps even more important because of preventing overuse injuries. Differences were also found between age groups with older players, older players shown to be stronger than the younger players. In the article by Naughton, Farpour-Lambert, Carlson, Bradney \& Praagh (2000), it was found that strength can be developed through training it is also a natural part of growth and maturation. The gender differences that are visible in general life, such as males being stronger than females, are also found in the current review with respect to tennis players. Not only strength is important for tennis, explosive movements for which power is needed are required as well. Greater power allows a tennis player to respond more quickly and to produce forceful movements with less effort. Players with greater power get into position quickly and can make effective shots (Roetert et al., 1995). Earlier research showed that power increases until 14 years of age and after this age a plateau would be reached (Malina, Bouchard \& BarOr, 2004; Wilmore \& Costill, 1999). This idea is not found in the current review where it was found that power increases in talented tennis players at least until the age of 16. The males in the current review scored higher on all tests than did females, perhaps due to gender specific differences in body compositions and hormones (Praagh et al., 2002; Naughton et al., 2000). As well, elite players scored higher than the sub-elite or non-elite players explained perhaps by greater levels of training (Elferink-Gemser, Visscher, Duijn \& Lemmink, 2006; Praagh et al., 2002) No article was found that looked at the training hours of elite tennis players and sub-elite tennis players, further research is necessary to look at the differences in training hours between elite and sub-elite tennis players.

No articles were found concerning anaerobic and aerobic muscular endurance development in talented tennis players. One reason might be that coaches are not as interested in muscular endurance as in the physical aspects such as speed, agility, power, strength and aerobic endurance. It was found that aerobic endurance increases with age (Baxter-Jones et al., 1993). In the study by Baxter-Jones et al. (1993) that followed 453 young athletes drawn from soccer, swimming, gymnastics, and tennis for three years. With $8,10,12$, 14 and 16 years of age it was found that the $\mathrm{VO}_{2}$ max of males increased significantly with increasing ages where as females showed a similar pattern. However, the significant increase in $\mathrm{VO}_{2} \max$ found in males in the latter stages of puberty was not shown in females. This is also found in the current review, however, with females' aerobic performance slightly decreased after the age of 16. An explanation for this would be that $\mathrm{VO}_{2}$ max increases with body weight and females that are 16 years old do not increase their body weight much anymore (Baxter-Jones et al., 1993). In the study by Naughton et al. (2000), it was found that females develop $\mathrm{VO}_{2}$ max less well than do males. 
Elferink-Gemser et al. (2006) showed as well that females develop their $\mathrm{VO}_{2}$ max until the age of 16 and after that age a plateau is reached.

With respect to the auxillary component, external shoulder rotation increases with age as part of flexibility. The increases in shoulder external rotation in tennis players is also a likely adaptation to the tennis serve (Chandler et al., 1990). Furthermore, the internal shoulder rotation decreases with age with tennis players especially on the dominant side (Berg et al., 2006; Chandler et al., 1990). The decrease in shoulder internal rotation, particularly on the dominant side, can be explained as an adaptation of the posterior shoulder musculature to the tennis stroke (Chandler et al., 1992). Tennis athletes showed a greater internal shoulder rotation in their dominant arm than other athletes, however, they also have a smaller range of external rotation (Kovacs, 2006). Tightness in internal rotation in tennis players can be a source of potential injury and decreased performances (Chandler et al., 1990). With respect to the hamstring flexibility, it was found that this is reasonably stable during the ages of 5 to $1 \mathrm{I}$ years, after which it increases up until the age of 15 (Berg et al., 2006). Early maturation girls showed more flexibility than the middle and late maturation girls. Young elite tennis players have better flexibility than young sub-elite tennis players. This could be a result of elite players knowing the importance of good hamstring flexibility and perhaps thereby training more on flexibility than do sub-elite players. Hamstring flexibility is important for stopping, starting, running, and jumping on the tennis court (Roetert et al., 1995). Hip flexibility is lower in elite than nonelite players (Bloomfield et al., 1984). In this review, hip flexibility is measured only at male elite tennis players and could not be compared with another group of players. The overall finding for flexibility is that flexibility decreases with age. Perhaps the idea that a baby is very flexible and if a child does not train his or her flexibility it decreases could explain why flexibility decreases with age. This also seems the case with tennis players, but further research is necessary to explain why flexibility decreases with age. Perhaps tennis players should pay more attention to their flexibility and the importance of flexibility in reducing injuries.

In general, the groups of players tested on physical skills were rather small. Only the study by Roetert et al. (1995) used large groups of players. However, the population of talented tennis players is not very large in general. As well, the countries of the studies differ. Most studies were conducted in the USA although there are also studies conducted in Denmark and South Africa. Most of the studies are also cross-sectional in nature while longitudinal studies would be preferred for following the observation of development of talented tennis players. A recommendation for further research would thus be to do a longitudinal study. The current review suggests that many differences between countries and studies exist in the way development in young talented tennis 
players is measured. A worldwide protocol in which the test procedure of development of tennis players would be described is recommended. The results of this current review suggest that it is important to develop all three physical components, anaerobic, aerobic and auxillary, to become a professional tennis player. Differences exist between the development of males and females as well as between elite and sub-elite tennis players. A worldwide protocol which describes the way in which physical development in young talented tennis players should be measured ideally, is also needed. This could be done by means of a standardized protocol for different levels and age groups, so that these groups can be compared with each other. Therefore it is necessary to conclude what qualities are required during youth to ultimately reach the top in tennis.

\section{REFERENCES}

Armstrong N, Welsman J, \& Winsley R (1996). Is peak VO2 a maximal index of children's aerobic fitness? International Journal of Sports Medicine., 17, 356-359.

Australian Coaching Council (1998). 20m shuttle run test. Australian sport commission: Belconnen, ACT.

Banzer W, Thiel C, Rosenhagen A, \& Vogt $L$ (2008). Tennis ranking related to exercise capacity. British Journal of Sports Medicine, 42, I52-I 54.

Baxter-Jones A, Goldstein H, \& Helms P (1993). The development of aerobic power in young athletes. Journal of Applied Physiology, 75, I I 60- I 167.

Bencke J, Damsgaard R, Saekmose A, Jorgensen P, Jorgensen K, \& Klausen K (2002). Anaerobic power and muscle strength characteristics of II years old elite and non-elite boys and girls from gymnastics, team handball, tennis and swimming. Scandinavian Journal of Medicine \& Science in Sports, 12, 17I- 178.

Berg Lvd, Coetzee B, \& Pienaar AE (2006). The influence of maturation on physical and motor performance talent identification determinants of $U-14$ provincial girl tennis players. Journal of Human Movement Studies, 50, 273-290.

Bergeron MF, Maresh CM, Kraemer WJ, Abraham A, Conroy B, \& Gabaree C (199|). Tennis: a physiological profile during match play. International Journal of Sports Medicine, 12, 474-479.

Bloomfield J, Blanksby BA, Beard DF, Ackland TR, \& Elliott BC (1984). Biological characteristics of young swimmers, tennis players and non-competitors. British Journal of Sports Medicine, 18, 97-103.

Chandler TJ, Kibler WB, Stracener EC, Ziegler AK, \& Pace B (1992). Shoulder strength, power, and endurance in college tennis players. The American Journal of Sports Medicine, 20, 455-458.

Chandler TJ, Kibler WB, Uhl TL, Wooten B, Kiser A, \& Stone E (1990). Flexibility comparisons of junior elite tennis players to other athletes. The American Journal of Sports Medicine, 18, 134-136.

Clarke HH (1976). Application of measurement to health and physical education. New Jersey: Prentice-Hall.

Cooke K, \& Davey P (2008). Predictors of oxygen uptake and performance during tennis. International Journal of Sports Medicine, 29, 34-39. 
Elferink-Gemser MT, Visscher C, Lemmink KAPM, Mulder Th (2004). Relation between multidimensional performance characteristics and level of performance in talented youth field hockey players. Journal of Sports Sciences, 22, I053- 1063.

Elferink-Gemser MT, Visscher C, van Duijn MA, \& Lemmink KAPM (2006). Development of the interval endurance capacity in elite and sub-elite youth field hockey players. British Journal of Sports Medicine, 40, 340-345.

Faff J, Ladyga M, \& Starczewska-Czapowska J (2000). Physical fitness of the top Polish male and female tennis players aged from twelve years to senior category. Biology of Sport, 17, 179-192.

Fernandez J, Mendez-Villanueva A, \& Pluim BM (2006). Intensity of tennis match play. British Journal of Sports Medicine, 40, 387-39l.

Girard O, Chevalier R, Leveque F, Micallef JP, \& Millet GP (2006). Specific incremental field test for aerobic fitness in tennis. British Journal of Sports Medicine,. 40, 79I-796.

Helsen WF, Hodges NJ, Van Winckel J and Starkes JL (2000). The roles of talent, physical precocity and practice in the development of soccer expertise. Journal of Sports Sciences, 18, 727-736.

Howe MJA, Davidson JW and Sloboda JA (1998). Innate talents: Reality or myth. Behavioral and Brain Sciences, 21, 399-442.

Kibler WB, \& Chandler TJ (2003). Range of motion in junior tennis players participating in an injury risk modification program. Journal of Sports Science and Medicine, 6, 5I-62.

Kovacs MS (2006). Applied physiology of tennis performance. British Journal of Sports Medicine, 40, 38I-385.

Kovacs MS (2007). Tennis physiology: training the competitive athlete. Sports Medicine, 37, $189-198$.

Kovacs MS, Pritchett R, Wickwire PJ, Green JM, \& Bishop P (2007). Physical performance changes after unsupervised training during the autumn/spring semester break in competitive tennis players. British Journal of Sports Medicine, 4I, 705-710.

Kraemer WJ, Hakkinen K, Triplett-Mcbride NT, Fry AC, Koziris, LP, Ratamess NA, Bauer JE, Volek JS, McConnell T, Newton RU, Gordon SE, Cummings D, Hauth J, Pullo F, Lynch JM, Fleck SJ, Mazzetti SA, \& Knuttgen HG (2003). Physiological changes with periodized resistance training in women tennis players. Medicine \& Science in Sports \& Exercise, 35, 157- 168.

Leone M, Lariviere G, \& Comtois AS (2002). Discriminant analysis of anthropometric and biomotor variables among elite adolescent female athletes in four sports. Journal of Sports Sciences, 20, 443-449.

MacCurdy D (2006). Talent identification around the world and recommendations for the chinese tennis association. ITF Coaching, I- 10.

Malina RM, Bouchard C, \& Bar-Or O (2004). Growth, maturation and physical activity. Champaign, IL: Human Kinetics Publishers.

Naughton G, Farpour-Lambert NJ, Carlson J, Bradney M, \& van Praagh PE (2000). Physiological issues surrounding the performance of adolescent athletes. Sports Medicine, 30, 309-325.

Nedeljkovic A, Mirkov DM, Kukolj M, Ugarkovic D, \& Jaric S (2007). Effect of maturation on the relationship between physical performance and body size. The Journal of Strength \& Conditioning Research,. 2 1, 245-250. 
Perry AC, Wang X, Feldman BB, Ruth T, \& Signorile J (2004). Can laboratory-based tennis profiles predict field tests of tennis performance? The Journal of Strength \& Conditioning Research, 18, 136-143.

Praagh Ev, \& Dore E (2002). Short-term muscle power during growth and maturation. Sports Medicine, 32, 701-728.

Roetert EP, Garrett GE, \& Brown SW (1992). Performance profiles of nationally ranked junior tennis players. Journal of Applied Sport Science Research, 6, 225-231.

Roetert EP, Piorkowski PA, Woods RB, \& Brown SW (1995). Establishing percentiles for junior tennis players based on physical fitness testing results. Clinics in Sports Medicine, 14, |-21.

Roetert P, \& Ellenbecker TS (1998). Complete conditioning for tennis. Champaign: Human Kinetics Publisher.

Rosch D, Hodgson R, Peterson TL, Graf-Baumann T, Junge A, Chomiak J, \& Dvorak J (2000). Assessment and evaluation of football performance. The American Journal of Sports Medicine, 28, S29-S39.

Ross MD, Nordeen MH, \& Barido M (2003). Test-retest reliability of Patrick's hip range of motion test in healthy college-aged men. The Journal of Strength \& Conditioning Research, 17, 156-161.

Salonikidis K, \& Zafeiridis A (2008). The effects of plyometric, tennis-drills, and combined training on reaction, lateral and linear speed, power, and strength in novice tennis players. The Journal of Strength \& Conditioning Research, 22, 182-191.

United States Tennis Association (1998). Complete Conditioning for Tennis. Champaign, IL: Human Kinetics.

Vanderford ML, Meyers MC, Skelly WA, Stewart CC, \& Hamilton KL (2004). Physiological and sport-specific skill response of olympic youth soccer athletes. The Journal of Strength \& Conditioning Research, 18, 334-342.

Wilmore JH, \& Costill DL (1999). Physiology of sport and exercise. Champaign, IL: Human Kinetics Publishers. 


\section{APPENDIX}

Table I. Results of the anaerobic development of young tennis players regarding the aspects speed and agility.

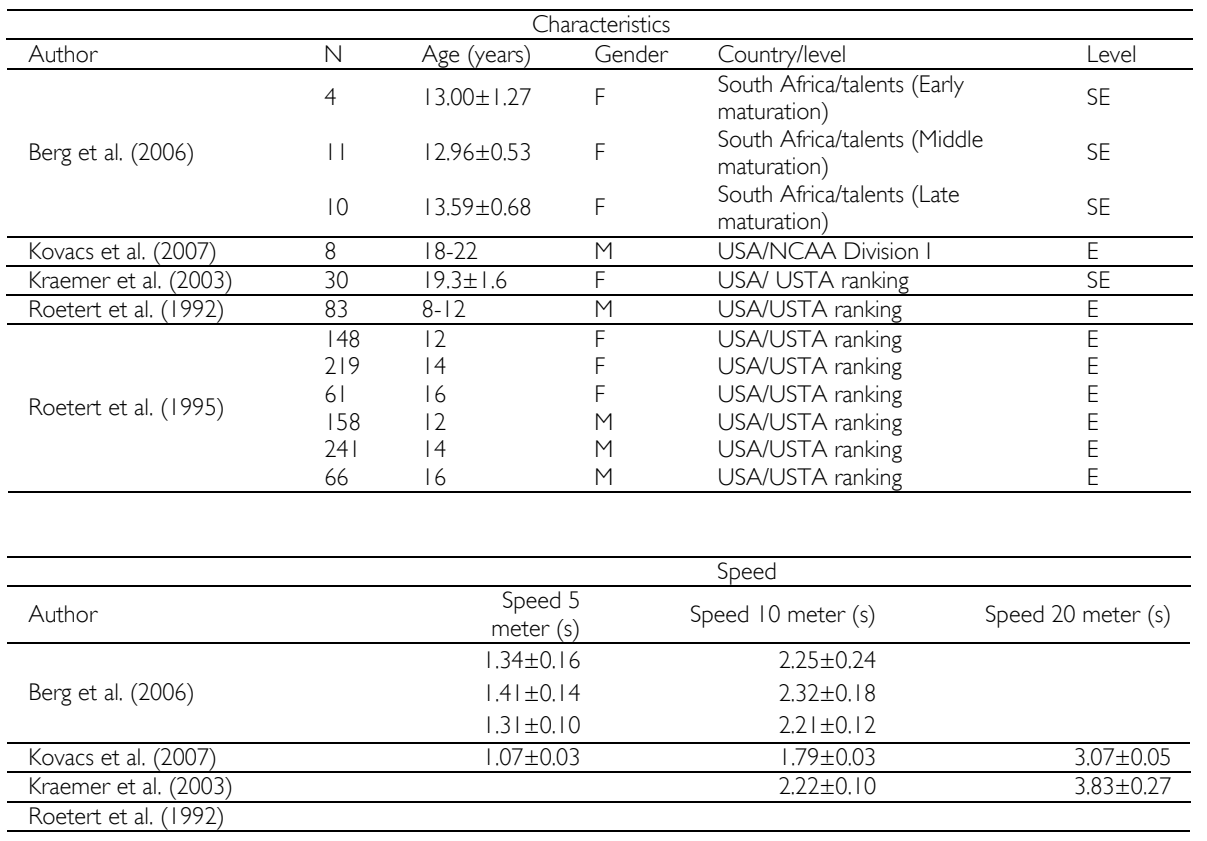

\begin{tabular}{|c|c|c|c|c|}
\hline & \multicolumn{4}{|c|}{ Agility } \\
\hline Author & AIS (s) & Spider test (s) & $\begin{array}{l}\text { Lateral agility test } \\
(\mathrm{s})\end{array}$ & Hexagon test (s) \\
\hline \multirow{3}{*}{ Berg et al. (2006) } & $9.46 \pm 0.77$ & & & \\
\hline & $9.57 \pm 0.61$ & & & \\
\hline & $9.39 \pm 0.75$ & & & \\
\hline Kovacs et al. (2007) & & $16.50 \pm 0.17$ & & \\
\hline Kraemer et al. (2003) & & & $7.07 \pm 0.95$ & \\
\hline Roetert et al. (1992) & & $18.85 \pm 1.26$ & & $15.93 \pm 2.66$ \\
\hline \multirow{6}{*}{ Roetert et al. (1995) } & & $<17.2$ & $<6.4$ & $<10.4$ \\
\hline & & $<16.7$ & $<6.2$ & $<10.0$ \\
\hline & & $<16.6$ & $<6.0$ & $<9.9$ \\
\hline & & $<17.0$ & $<6.4$ & $<10.6$ \\
\hline & & $<15.8$ & $<6.0$ & $<10.3$ \\
\hline & & $<15.0$ & $<5.7$ & $<10.0$ \\
\hline
\end{tabular}


Table 2. Results of the anaerobic development of young tennis players regarding the aspect strength.

\begin{tabular}{|c|c|c|c|c|c|}
\hline Author & $\mathrm{N}$ & Age (years) & Gender & Country/level & Level \\
\hline \multirow{4}{*}{ Bencke et al. (2002) } & 6 & $11.9(10.0-12.2)$ & $\mathrm{F}$ & Denmark/Elite & E \\
\hline & 7 & $11.7(9.4-12.7)$ & $F$ & Denmark/NonElite & NE \\
\hline & 12 & $11.9(10.5-12.7)$ & M & Denmark/Elite & E \\
\hline & 12 & $11.1(10.0-12.7)$ & M & Denmark/NonElite & NE \\
\hline \multirow{3}{*}{ Berg et al. (2006) } & 4 & $13.00 \pm 1.27$ & $\mathrm{~F}$ & \multirow{2}{*}{$\begin{array}{l}\text { South Africa/talents (Early } \\
\text { maturation) } \\
\text { South Africa/talents (Middle } \\
\text { maturation) }\end{array}$} & SE \\
\hline & 11 & $12.96 \pm 0.53$ & $\mathrm{~F}$ & & SE \\
\hline & 10 & $13.59 \pm 0.68$ & $\mathrm{~F}$ & $\begin{array}{l}\text { South Africa/talents (Late } \\
\text { maturation) }\end{array}$ & SE \\
\hline \multirow{3}{*}{ Bloomfield et al. (1984) } & 10 & $7-8$ & F/M & Australia/Elite & $E$ \\
\hline & 32 & $9-10$ & $F / M$ & Australia/Elite & $\mathrm{E}$ \\
\hline & 23 & $11-12$ & F/M & Australia/Elite & $\mathrm{E}$ \\
\hline Kovacs et al. (2007) & 8 & $18-22$ & M & USA/NCAA Division I & $\mathrm{E}$ \\
\hline Kraemer et al. (2003) & 30 & $19.3 \pm 1.6$ & $\mathrm{~F}$ & USA/ USTA ranking & SE \\
\hline Roetert et al. (1992) & 83 & $8-12$ & $M$ & USA/USTA ranking & $\mathrm{E}$ \\
\hline Author & & $\begin{array}{r}\text { Grip strength } \\
\text { Dominant hand } \\
(\mathrm{kg})\end{array}$ & $\begin{array}{r}\text { Grip strength } \\
\text { non dominant } \\
\text { hand }(\mathrm{kg})\end{array}$ & $\begin{array}{r}\text { Dominant arm } \\
\text { Flexion } \\
\text { Isometric }(\mathrm{kg}) \\
\end{array}$ & $\begin{array}{r}\text { Dominant arm } \\
\text { extension } \\
\text { isomotric }(\mathrm{kg})\end{array}$ \\
\hline Bencke et al. (2002) & & & & $\begin{array}{l}25.3(21.2-45.7) \\
20.1(11.4-39.1) \\
30.0(16.7-48.0) \\
25.6(20.6-37.5)\end{array}$ & $\begin{array}{l}.5(21.8-47.2) \\
.8(11.6-37.7) \\
.7(16.2-55.0) \\
.4(24.9-38.3)\end{array}$ \\
\hline Berg et al. (2006) & & $\begin{array}{l}33.37 \pm 6.60 \\
29.63 \pm 4.64 \\
29.00 \pm 6.05\end{array}$ & $\begin{array}{l}27.00 \pm 6.00 \\
25.77 \pm 4.62 \\
24.05 \pm 4.75\end{array}$ & & \\
\hline Bloomfield et al. (1984) & & $\begin{array}{r}7.4 \pm 2.9 \\
11.0 \pm 2.5 \\
15.0 \pm 3.4 \\
\end{array}$ & & & $\begin{array}{l}15.8 \pm 3.2 \\
18.8 \pm 3.7 \\
20.4 \pm 4.8 \\
\end{array}$ \\
\hline Kovacs et al. (2007) & & $53.13 \pm 1.79$ & $46.00 \pm 2.28$ & & \\
\hline Kraemer et al. (2003) & & $\begin{array}{r}330.6 \pm 40.3 \\
\text { (newton) }\end{array}$ & $\begin{array}{r}261.9 \pm 20.6 \\
\text { (newton) }\end{array}$ & & \\
\hline Roetert et al. (1992) & & $21.95 \pm 5.77$ & $18.55 \pm 5.08$ & & \\
\hline Author & & $\begin{array}{r}\text { Non Dominant } \\
\text { arm flexion } \\
\text { isometric }(\mathrm{kg})\end{array}$ & $\begin{array}{l}\text { Non Dominant } \\
\text { arm extension } \\
\text { Isometric }(\mathrm{kg})\end{array}$ & $\begin{array}{l}\text { Thigh flexion } \\
\text { strength }(\mathrm{kg})\end{array}$ & $\begin{array}{l}\text { Leg extension } \\
\text { strength }(\mathrm{kg})\end{array}$ \\
\hline Bencke et al. (2002) & & $\begin{array}{r}23.7(17.3-40.2) \\
25.3(9.6-41.9) \\
21.7(13.3-43.1) \\
24.9(16.232 .6) \\
\end{array}$ & $\begin{array}{l}26.1(18.8-34.6) \\
27.2(12.6-31.1) \\
28.8(14.1-52.1) \\
28.5(21.5-34.6)\end{array}$ & & \\
\hline Bloomfield et al. (1984) & & & & $\begin{array}{l}22.4 \pm 2.9 \\
28.8 \pm 4.6 \\
33.5 \pm 9.0\end{array}$ & $\begin{array}{l}26.9 \pm 5.3 \\
32.1 \pm 5.9 \\
36.4 \pm 8.2\end{array}$ \\
\hline
\end{tabular}


Table 3. Results of the anaerobic development of young tennis players regarding the aspect power

\begin{tabular}{|c|c|c|c|c|c|}
\hline Author & $\mathrm{N}$ & Age (years) & Gender & Country & Level \\
\hline \multirow{4}{*}{ Bencke et al. (2002) } & 6 & $11.9(10.0-12.2)$ & $\mathrm{F}$ & Denmark/Elite & $\mathrm{E}$ \\
\hline & 7 & $11.7(9.4-12.7)$ & $\mathrm{F}$ & Denmark/NonElite & NE \\
\hline & 12 & $11.9(10.5-12.7)$ & M & Denmark/Elite & $E$ \\
\hline & 12 & $11.1(10.0-12.7)$ & $M$ & Denmark/NonElite & $\mathrm{NE}$ \\
\hline \multirow{3}{*}{ Berg et al. (2006) } & 4 & $13.00 \pm 1.27$ & $\mathrm{~F}$ & $\begin{array}{l}\text { South Africa/talents (Early } \\
\text { maturation) }\end{array}$ & SE \\
\hline & 11 & $12.96 \pm 0.53$ & $\mathrm{~F}$ & $\begin{array}{l}\text { South Africa/talents (Middle } \\
\text { maturation) }\end{array}$ & SE \\
\hline & 10 & $13.59 \pm 0.68$ & $\mathrm{~F}$ & $\begin{array}{l}\text { South Africa/talents (Late } \\
\text { maturation) }\end{array}$ & SE \\
\hline \multirow{3}{*}{ Bloomfield et al. (1984) } & 10 & $7-8$ & F/M & Australia/Elite & $E$ \\
\hline & 32 & $9-10$ & $F / M$ & Australia/Elite & $\mathrm{E}$ \\
\hline & 23 & $11-12$ & $\mathrm{~F} / \mathrm{M}$ & Australia/Elite & E \\
\hline Kovacs et al. (2007) & 8 & $18-22$ & $M$ & USA/NCAA Division I & $E$ \\
\hline Kraemer et al. (2003) & 30 & $19.3 \pm 1.6$ & $\mathrm{~F}$ & USA/ USTA ranking & SE \\
\hline Roetert et al. (1992) & 83 & $8-12$ & $M$ & USA/USTA ranking & $\mathrm{E}$ \\
\hline \multirow{6}{*}{ Roetert et al. (1995) } & 148 & 12 & $\mathrm{~F}$ & USA/USTA ranking & $E$ \\
\hline & 219 & 14 & $\mathrm{~F}$ & USA/USTA ranking & $\mathrm{E}$ \\
\hline & 61 & 16 & $\mathrm{~F}$ & USA/USTA ranking & $\mathrm{E}$ \\
\hline & 158 & 12 & $M$ & USA/USTA ranking & $\mathrm{E}$ \\
\hline & 241 & 14 & $M$ & USA/USTA ranking & $\mathrm{E}$ \\
\hline & 66 & 16 & M & USA/USTA ranking & E \\
\hline Author & $\begin{array}{l}\mathrm{Ve} \\
\mathrm{mov}\end{array}$ & $\begin{array}{l}\text { I counter } \\
\text { ent Jump } \\
(\mathrm{cm})\end{array}$ & $\begin{array}{r}\text { Squat jump } \\
(\mathrm{cm})\end{array}$ & $\begin{array}{r}\text { Wingate test } \\
\text { (Watt) }\end{array}$ & $\begin{array}{r}\text { WIngate test } \\
\text { (watts } / \mathrm{kg} \text { ) }\end{array}$ \\
\hline \multirow{4}{*}{ Bencke et al. (2002) } & & $5(22-27)$ & $23.0(22-26)$ & $279(233-433)$ & $7.2(6.4-7.7)$ \\
\hline & & $0(20-33)$ & $23.0(20-30)$ & $317(186-418)$ & $7.5(5.9-8.8)$ \\
\hline & & $0(21-36)$ & $25.5(19-29)$ & 314 (205-529) & $7.4(6.7-9.1)$ \\
\hline & & $5(21-34)$ & $24.5(19-28)$ & $272(232-430)$ & $7.3(6.7-8.3)$ \\
\hline \multirow{3}{*}{ Berg et al. (2006) } & & $.75 \pm 4.71$ & & & \\
\hline & & $.86 \pm 4.68$ & & & \\
\hline & & $.25 \pm 7.64$ & & & \\
\hline \multirow{3}{*}{ Bloomfield et al. (1984) } & & $20 \pm 4$ & & & \\
\hline & & $25 \pm 5$ & & & \\
\hline & & $28 \pm 6$ & & & \\
\hline Kovacs et al. (2007) & & & & & $8.53 \pm 0.19$ \\
\hline Kraemer et al. (2003) & & $40 \pm 8$ & & $570 \pm 78$ & \\
\hline Roetert et al. (1992) & & $.88 \pm 6.05$ & & & \\
\hline \multirow{6}{*}{ Roetert et al. (1995) } & & $>39.62$ & & & \\
\hline & & $>47.24$ & & & \\
\hline & & $>48.26$ & & & \\
\hline & & $>43.94$ & & & \\
\hline & & $>52.58$ & & & \\
\hline & & $>63.75$ & & & \\
\hline
\end{tabular}


Table 4. Results of the aerobic development of young tennis players regarding the aspect aerobic endurance

\begin{tabular}{|c|c|c|c|c|c|}
\hline Author & $\mathrm{N}$ & Age (years) & Gender & Country/level & Level \\
\hline \multirow{2}{*}{ Armstrong et al. (1996) } & 18 & $9.9 \pm 0.4$ & $\mathrm{~F}$ & UK/-- & -- \\
\hline & 17 & $9.9 \pm 0.4$ & M & UK/-- & -- \\
\hline \multirow{6}{*}{ Baxter-Jones et al. (1993) } & & $10.7 \pm 0.8$ & $F$ & UK/young athletes & $E$ \\
\hline & 160 & $12.0 \pm 1.0$ & $\mathrm{~F}$ & UK/young athletes & $E$ \\
\hline & & $15.5 \pm 1.9$ & $\mathrm{~F}$ & UK/young athletes & $E$ \\
\hline & & $11.6 \pm 1.3$ & M & UK/young athletes & $E$ \\
\hline & 149 & $13.0 \pm 1.2$ & M & UK/young athletes & $E$ \\
\hline & & $16.2 \pm 1.7$ & M & UK/young athletes & E \\
\hline \multirow{3}{*}{ Berg et al. (2006) } & 4 & $13.00 \pm 1.27$ & $\mathrm{~F}$ & $\begin{array}{l}\text { South Africa/talents (Early } \\
\text { maturation) }\end{array}$ & SE \\
\hline & 11 & $12.96 \pm 0.53$ & $\mathrm{~F}$ & $\begin{array}{l}\text { South Africa/talents (Middle } \\
\text { maturation) }\end{array}$ & SE \\
\hline & 10 & $13.59 \pm 0.68$ & $\mathrm{~F}$ & $\begin{array}{l}\text { South Africa/talents (Late } \\
\text { maturation) }\end{array}$ & SE \\
\hline Bergeron et al. (199|) & 10 & $20.3 \pm 2.5$ & $M$ & USA/Division I & SE \\
\hline \multirow{2}{*}{ Cooke et al. (2008) } & 8 & $23 \pm 8$ & $\mathrm{~F}$ & $\begin{array}{l}\text { Republic of Singapore/ rating } 3.1 \\
\text { or lower }\end{array}$ & SE \\
\hline & 8 & $20 \pm 6$ & M & $\begin{array}{l}\text { Republic of Singapore/ rating } 3.1 \\
\text { or lower }\end{array}$ & SE \\
\hline \multirow{12}{*}{ Faff et al. (2000) } & 7 & $12.0-13.0$ & M & Poland/ top tennis players & $E$ \\
\hline & 10 & $13.1-14.0$ & M & Poland/ top tennis players & $E$ \\
\hline & 15 & $14.1-15.0$ & M & Poland/ top tennis players & $E$ \\
\hline & 17 & $15.1-16.0$ & M & Poland/ top tennis players & $E$ \\
\hline & 14 & $16.1-18.0$ & M & Poland/ top tennis players & $E$ \\
\hline & 9 & $>18.0$ & M & Poland/ top tennis players & $E$ \\
\hline & 6 & $12.0-13.0$ & $\mathrm{~F}$ & Poland/ top tennis players & $E$ \\
\hline & 17 & $13.1-14.0$ & $\mathrm{~F}$ & Poland/ top tennis players & $E$ \\
\hline & 12 & $14.1-15.0$ & $\mathrm{~F}$ & Poland/ top tennis players & $E$ \\
\hline & 16 & $15.1-16.0$ & $\mathrm{~F}$ & Poland/ top tennis players & $E$ \\
\hline & 4 & $16.1-18.0$ & $\mathrm{~F}$ & Poland/ top tennis players & $E$ \\
\hline & 6 & $>18.0$ & $\mathrm{~F}$ & Poland/ top tennis players & $E$ \\
\hline Girard et al. (2006) & 9 & $16.0 \pm 1.6$ & $M$ & France/junior competitive & E/NE \\
\hline Kovacs et al. (2007) & 8 & $18-22$ & $M$ & USA/NCAA Division I & $\mathrm{E}$ \\
\hline Kraemer et al. (2003) & 30 & $19.3 \pm 1.6$ & $\mathrm{~F}$ & USA/ USTA ranking & SE \\
\hline Leone et al. (2002) & 15 & $13.9 \pm 1.3$ & $\mathrm{~F}$ & Canada/elite & $E$ \\
\hline \multirow{2}{*}{ Perry et al. (2004) } & 10 & $14.70 \pm 1.49$ & $F$ & USA/USTA ranking & $E$ \\
\hline & 23 & $|5.09 \pm 1.3|$ & M & USA/USTA ranking & $E$ \\
\hline Roetert et al. (1992) & 83 & $8-12$ & $M$ & USA/USTA ranking & $E$ \\
\hline \multirow{5}{*}{ Roetert et al. (1995) } & 148 & 12 & $F$ & USA/USTA ranking & $E$ \\
\hline & 219 & 14 & $\mathrm{~F}$ & USA/USTA ranking & $E$ \\
\hline & 61 & 16 & $F$ & USA/USTA ranking & $E$ \\
\hline & 158 & 12 & M & USA/USTA ranking & $E$ \\
\hline & 241 & 14 & M & USA/USTA ranking & $E$ \\
\hline
\end{tabular}




\begin{tabular}{|c|c|c|c|c|c|}
\hline Author & $\begin{array}{r}\mathrm{VO}_{2} \max \\
(\mathrm{ml} / \mathrm{kg} / \mathrm{min}) \\
(\text { treadmill) }\end{array}$ & $\begin{array}{r}\text { Heart rate } \\
\text { (beats/min) } \\
\text { during } \\
\text { treadmill } \\
\end{array}$ & $\begin{array}{r}\text { Heart rate } \\
\text { during match } \\
\text { play } \\
\text { (beats/min) }\end{array}$ & $\begin{array}{r}\text { Shuttle run } \\
\text { test } \\
\text { (Level) }\end{array}$ & $\begin{array}{l}\mid 1 / 2 \text { mile run } \\
\text { (min:sec) }\end{array}$ \\
\hline \multirow{2}{*}{ Armstrong et al. (1993) } & $51 \pm 6$ & $211 \pm 9$ & & & \\
\hline & $62 \pm 6$ & $203 \pm 3$ & & & \\
\hline \multirow{6}{*}{ Baxter-Jones et al. (1993) } & $47.4 \pm 5.8$ & & & & \\
\hline & $48.6 \pm 5.3$ & & & & \\
\hline & $47.1 \pm 5.3$ & & & & \\
\hline & $54.1 \pm 5.2$ & & & & \\
\hline & $57.6 \pm 5.6$ & & & & \\
\hline & $59.5 \pm 6.1$ & & & & \\
\hline \multirow{3}{*}{ Berg et al. (2006) } & & & & $6.80 \pm 1.08$ & \\
\hline & & & & $7.35 \pm 1.59$ & \\
\hline & & & & $7.15 \pm 0.74$ & \\
\hline Bergeron et al. (|99|) & $58.5 \pm 9.4$ & $195.6 \pm 6.3$ & $144.6 \pm 13.2$ & & \\
\hline \multirow{2}{*}{ Cooke et al. (2008) } & $52.8 \pm 6.8$ & & & & \\
\hline & $64.8 \pm 6.8$ & & & & \\
\hline \multirow{12}{*}{ Faff et al. (2000) } & $55.8 \pm 4.4$ & $198 \pm 6$ & & & \\
\hline & $60.1 \pm 2.4$ & $202 \pm 9$ & & & \\
\hline & $61.0 \pm 3.6$ & $201 \pm 4$ & & & \\
\hline & $60.6 \pm 3.6$ & $197 \pm 8$ & & & \\
\hline & $59.7 \pm 4.6$ & $196 \pm 7$ & & & \\
\hline & $62.3 \pm 4.8$ & $197 \pm 9$ & & & \\
\hline & $54.7 \pm 5.2$ & $205 \pm 11$ & & & \\
\hline & $56.2 \pm 5.1$ & $204 \pm 7$ & & & \\
\hline & $53.5 \pm 4.4$ & $204 \pm 8$ & & & \\
\hline & $52.5 \pm 3.2$ & $201 \pm 7$ & & & \\
\hline & $56.6 \pm 3.2$ & $201 \pm 5$ & & & \\
\hline & $55.8 \pm 3.3$ & $190 \pm 11$ & & & \\
\hline Girard et al. (2006) & $57.4 \pm 6.4$ & $194.3 \pm 6.7$ & & & \\
\hline Kovacs et al. (2007) & $53.9 \pm 1.11$ & & & & \\
\hline Kraemer et al. (2003) & $45.7 \pm 2.2$ & & & & \\
\hline Leobe et al. (2002) & $49.5 \pm 4.4$ & & & & \\
\hline \multirow{2}{*}{ Perry et al. (2004) } & $45.62 \pm 4.72$ & & & & \\
\hline & $56.01 \pm 5.66$ & & & & \\
\hline \multirow[t]{2}{*}{ Roetert et al. (1992) } & & & & & $755.17 \pm 111.4$ \\
\hline & & & & & $\begin{array}{r}8 \\
<640\end{array}$ \\
\hline \multirow{4}{*}{ Roetert et al. (1995) } & & & & & $<630$ \\
\hline & & & & & $<615$ \\
\hline & & & & & $<600$ \\
\hline & & & & & $<565$ \\
\hline
\end{tabular}


Table 5. Results of the auxillary development of young tennis players regarding the aspect flexibility

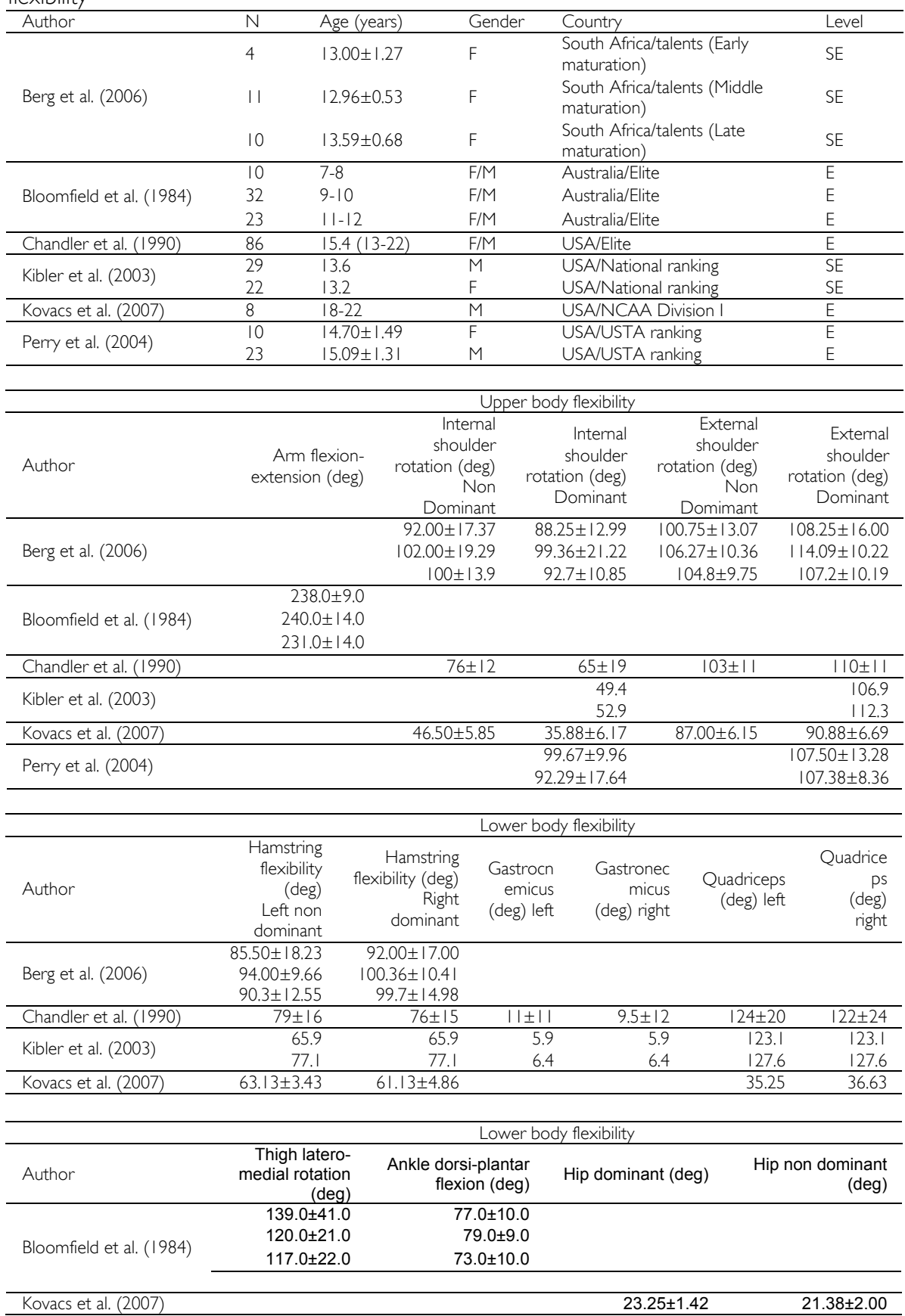

